\title{
PRACTICAL ASPECTS OF DAILY POLLEN CENSUS
}

\author{
W. J. QUARLES VAN UFFORD
}

Department for Allergic Diseases, Diaconessenhuis, Utrecht (The Netherlands)

(Received April 3, 1967)

(Resubmitted May 3, 1967)

\section{SUMMARY}

It is important for diagnostic purposes to keep a daily pollen count. Correlating this with hayfever symptoms, it is then possible to gain insights into critical hours and circumstances which favor an outbreak. Thus we learn to predict the severity of a pollen season and to take preventive measures.

\section{INTRODUCTION}

This discussion about the practical aspects of a daily pollen census are from the point of view of an allergist-practitioner, rather than dealing with problems of a purely botanical nature.

GENERAL REMARKS

In a newspaper article announcing the Second International Conference on Palynology it was stated that this conference would deal with problems of life in remote times.

However, when doctors are gathered together for a palynological discussion, they are concerned primarily with the problems of life existing on the surface of the earth. The air we inhale into our lungs contains many small particles; during most of the year many of these particles are pollen grains.

Primitive pollination was by the simple, direct method of wind dispersal. The anemophilous plants send their pollen grains into the air. Under some conditions, such pollen grains can be allergens. When pollen grains are the cause of symptoms of disease in men or animals, we call such a complex of symptoms pollinosis.

Koch formulated a triad of postulates which must be fulfilled before bac- 
teria might be called the cause of a disease (TOPLEY and WILSON, 1938); Thommen (in CocA et al., 1931) formulated five postulates to be fulfilled before pollen grains might be declared to be the cause of the complex of symptoms called pollinosis:

(I) The pollen must contain an excitant of hayfever;

(2) The pollen must be anemophilous;

(3) It must be produced in sufficiently large quantities;

(4) It must be sufficiently buoyant to be carried considerable distances;

(5) The plant producing the pollen must be widely and abundantly distributed.

(These postulates apply to epidemic or endemic hayfever, not to incidental hayfever as this occurs in gardeners, florists, etc.)
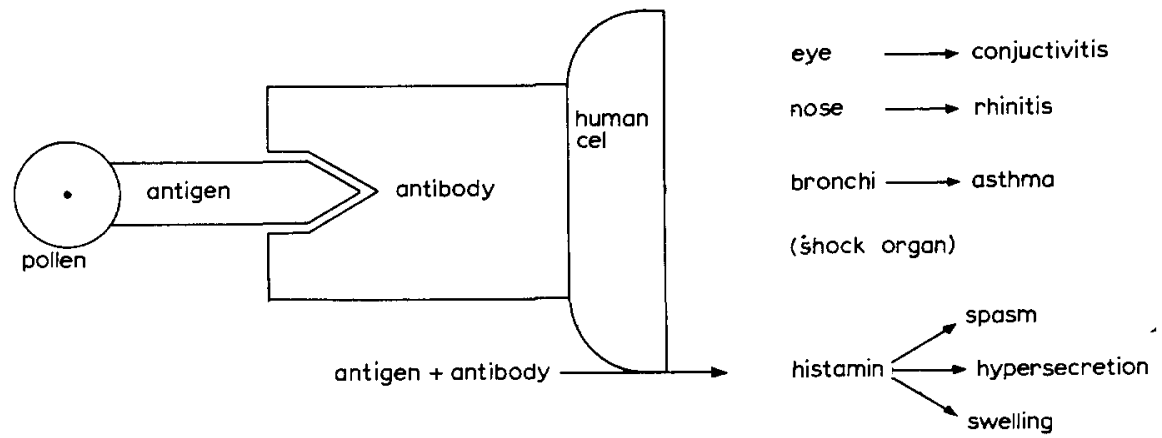

Fig.1. Allergic reactions of the human body to pollen.

These factors aroused medical interest, and allergists in particular were stimulated to pursue the study of pollen.

When a patient seeks medical help, and pollinosis is suspected, three questions have to be answered:

(1) Is the patient allergic to some kinds of pollen?

(2) Is contact with these kinds of pollen possible in his area?

(3) Do his symptoms correlate with the times during which these pollen grains arrive in, and disappear from, the air?

An important problem is the allergenicity of pollen grains. Does allergenicity differ in new and old pollen grains? Does transportation influence the allergenicity? The answers to these questions might be positive. In addition, there are several other factors which appear to be relevant:

(a) Humidity might be important. J. Liska (personal communication, 1967) conducted experiments between 1934-1936 in which he stored pollen grains after a delay of several days; these lost much of their allergenicity. Beginning in 1947, he stored the grains immediately in the exsiccator; in these, even after several years had passed, no loss of allergenicity could be demonstrated. 
(b) Differences from season to season. As wines differ from year to year, so do pollen grains, according to Liska. He proved that the protein-nitrogen content could change considerably from one year to another. For this reason he uses grains from different seasons in the preparation of his pollen extracts for use in treatment.

(c) Liska found that in some places even potent pollen grains did not cause hayfever symptoms. (Ionization of the air? Differences between granite or alluvium?)

In the U.S.A. a tremendous amount of work has been done by O.C. Durham and others to inform allergists about so-called regional allergy. Which kinds of pollen are found in the various states? Durham formulated three postulates (SAMTER and Durham, 1955):

(I) Number of pollen grains during the season.

(2) Number of pollen grains during one day.

(3) Number of days with a pollen count higher than 25.

CLINICAL VALUE

The results of a daily pollen census are important for diagnostic and therapeutic purposes in the treatment of hayfever. If a patient starts to sneeze or to wheeze, what might the cause be? Did he catch a cold the night before? Is he allergic to the hairs or the odors of animals or men? Is this his old disease---with his particular, well-known allergen-or is this his old disease with a new allergen? For the past twenty years the author's patients have been requested to keep records of their complaints. These records are studied: exacerbations might occur during weekends (house dust?), in a special season (bacteria, pollen, or molds?), sometimes on holidays (special contacts?) or high days (psychological influences?). Sometimes we find an explanation, but at other times we have to compare the patient's record with those prepared by botanists, mycologists, workers on airpollution studies, etc.

In many cases, the results of a daily pollen census are necessary as diagnostic aids. In Europe work in this field is still in an early stage. In the U.S.A. much has already been done. There they distinguish two hayfever seasons: one caused by grasses, the other by ragweed. Ragweed is still rare in Europe. However, J. Liska and J. Liskova (J. Liska, personal communication, 1967) found that during 1933-1935, $90 \%$ of their hayfever patients had complaints from the end of May until the middle of July (grasses) and that only $10 \%$ went on until September. But in 1960 , only $30 \%$ of their patients had limited complaints, and $70 \%$ had symptoms from May to autumn. The botanist might be able to offer an explanation for this. 
Specific therapeutic methods are: (1) hyposensitization, and (2) elimination. Some remarks should be made concerning therapeutic aspects:

(a) We would like to find Utopia Anallergica, the country without pollen where our patients can stay without complaints. To discover such a country we would have to take daily pollen census during different seasons. Not merely would the vegetation have to be considered, but also the pollen grains transported by the wind.

Helgoland, the German North Sea island, has been claimed to be this Utopia for the Heufieber Bund.

(b) Pre- and co-seasonal registration of weather conditions, correlated with pollen graphs, inform us about the influence of weather conditions on the quantity of pollen grains in the air. This knowledge means that patients can receive instructions about dangerous times. In addition, the allergist can depend on preseasonal weather conditions to predict the severity of the pollen season and thus regulate hyposensitization schemes for patients. Important for allergists are two different days of onset: ( $l$ ) the day the hayfever symptoms start in nose, eyes, etc.; (2) the day the asthmatic symptoms start.

In general the hyposensitization course starts in January, with two or three injections a week, in an attempt to produce a form of protection by the time the hayfever begins.

In Belgium, the north of Germany, and The Netherlands, the hayfever season begins at the end of May (relatively few patients are allergic to tree pollen from February to April). It was curious that in 1966 in The Netherlands, and also in Belgium, complaints started two or more weeks in advance of the usual season. Two explanations seem possible: (a) predisposing factors in the patient (e.g., humidity increases hyperreactivity); (b) the rapid change in temperature brought into the air a higher concentration of pollen, or pollen which was stronger in allergenicity.

One of the author's patients, who suffers from hayfever and who is director of a cinema, slept in his theater during the second part of the hayfever season because there he experienced no asthma crises at night. After hyposensitization with pollen extract, he was able to sleep in his own room again.

The question still remains, however, why many hayfever patients have their complaints at night. Pollen counts taken over 24-h periods inform us about dangerous and more or less safe hours. In Practice of Allergy (VAUGHAN and BLACK, 1948), we find the statement that grass pollen has been caught in airplanes as high as $6 \mathrm{~km}$. Not infrequently, there is a higher concentration at an altitude of $1000-2000 \mathrm{~m}$ than nearer the ground surface. Pollen clouds result from air currents, and under appropriate conditions we can have pollen showers. These pollen showers may explain the increase of symptoms after sunset, as the air currents descend, rather than in the early hours of the morning when plants shed their pollen. Pollen showers might also explain the increase in symptoms during stormy 
weather or in cold winds. Storms (even with rain) are also responsible for bringing pollen into houses, thus causing more complaints.

PRACTICAL WORK

Determination of the identity of trees, grasses, and weeds, and the abundance of pollen they produce in a given location, is a purely local problem. A local research project should consist of four phases:

(1) The identification of the plants and their pollination dates.

(2) The collection of pollen grains (with records of abundance, weight, etc.).

(3) Determination of the distribution of each kind of pollen.

(4) The identification and examination of antigenic fractions.

In The Netherlands work on the identification and differentiation of grasses had already been done many years ago by BENJAMINS et al. (1923, 1924, 1926a,b, 1929). Presently there are four small laboratories preparing pollen extracts for hyposensitization. Hayfever is now so common that even in winter time sneezing might be called hayfever. A daily census was made in 1959 in Renkum, where the lessons of Professor F. P. Jonker and Mr. H. A. Hyde were brought into practice. Renkum has woods, grasses, and rye fields. Graphs by the present author (QUARLES VAN UFFORD, 1962) show that the number of pollen grains indeed correlated with the complaints of patients.

Clinical and botanical findings were compared with the 1959 report by the Royal Netherlands Meteorological Institute, De Bilt.

The conclusion has been drawn that relatively cool but very dry air coming from northerly directions was most liable to give rise to hayfever.

\section{DISCUSSION}

Some years ago the author proposed a collective European research program on the occurrence of pollen in different countries, in both space and time, on the relationship to weather conditions, etc. However, this work has not yet been started. Perhaps the international palynological organization now in development will be of help.

From the allergist's point of view, botanists are invited to help in the following aspects of pollen research:

(1) Allergenicity of pollen in different stadia.

(2) The relationships between pollen allergen and the mucosa of the nose.

(3) The daily census (day and night)

(4) Pollen occurrence in Europe.

(5) Why pollen grains, known to be in the air, at times cause no complaints. 


\section{REFERENCES}

Benjamins, C. E., Idzerda, J. en Uittien, H., 1923. Onderzoek naar hooikoorts verwekkende planten, 1. Ned. Tijdschr. Geneesk., 67(1): 330-341.

Benjamins, C. E., Idzerda, J. en UitTien, H., 1924. Onderzoek naar hooikoorts verwekkende planten, 2. Ned. Tijdschr. Geneesk., 68(1): 1838-1844.

Benjamins, C. E., IDzerda, J. en UitTiEn, H., 1926a. Onderzoek naar hooikoorts verwekkende planten. 3. Ned. Tijdschr. Geneesk., 70(1): 935-945.

Benjamins, C. E., Idzerda, J. en Uittien, H., 1926b. Onderzoek naar hooikoorts verwekkende planten, 4. Ned. Tijdschr. Geneesk., 70(2): 18-25.

Benjamins, C. E., Idzerda, J. en Nienhuis, J. H., 1929. Onderzoek naar hooikoorts verwekkende planten, 5. Ned. Tijdschr. Geneesk., 73(1): 143-150.

Coca, A. F., Walzer, M. and Thommen, A. A., 1931. Asthma and Hay Fever in Theory and Practice. Thomas, Springfield, Ill., 165 pp.

Quarles van Ufford, W. J., 1962. The 1959 hay-fever season. 4th Ann. Rept. Europ. Acad. Allergy, pp. 10-20.

SAmter, M. and Durham, O. C. (Editors), 1955. Regional Allergy of the United States, Canada, Mexico and Cuba. Thomas, Springfield, Ill., $395 \mathrm{pp}$.

Topley, W. W. C. and Wilson, G. S., 1938. The Principles of Bacteriology and Immunity, Arnold, London, 1645 pp.

Vaughan, W. T. and Black, J. H., 1948. Practice of Allergy. Mosby, St. Louis, Mo., 1132 pp.

\section{DISCUSSION}

Some comments on the evaluation of daily census-D. A. WILLIAMs, Asthma and Allergy Unit, Davids Hospital, Cardiff (Great Britain).

(I) Pollen studies have now been carried out at some fourteen stations covering Britain, and continuously at Cardiff from 1942 onwards (Hyde and Williams, 1953; HydE, 1955). The average grass-pollen count for the season 1943-1956, on the gravity slide at Cardiff, was 2,092 grains $/ 1 \mathrm{~cm}^{2}$. During the 14 years concerned, the count varied very widely, ranging from 45.5 per 100 of average in 1956 to 146.0 per 100 in 1952.

The highest daily count $\left(265\right.$ grains/ $1 \mathrm{~cm}^{2}$, June 14,1952$)$ probably corresponded with an atmospheric concentration of 500 grains $/ \mathrm{m}^{3}$ or more (HYDE, 1952, and Hyde, unpublished data, 1967). Some trees produce significant quantities of airborne pollen, most of them in the spring; thus the average annual incidence of oak (Quercus) pollen at Cardiff (which may probably be regarded as typical of southern Britain) is $17 \%$ of grass pollen, of birch (Betula) 8 per 100, and ash (Fraxinus) 7.5 per 100; plane trees (Plantanus) are extremely numerous in central London only, where the incidence of this kind of pollen may rise to over $110 \%$ of the average grass-pollen incidence at Cardiff. The flowering seasons of the different trees vary from year to year, and their pollen production much more so--even the most abundant falling in certain years to below 10 per 100 , or even below 5 per 100 of average (HYDE, 1956).

Nettle (Urtica) is outstanding among herbaceous pollen grains ("weeds"): its average annual incidence in some years approaches that of the grasses (H. A. Hyde, unpublished data, 1967). In the autumn, after the herbaceous-pollen season, pollen is virtually absent from the air.

(2) With regard to the clinical value of a daily census, it is important to become familiar with the variation of the pollen count from day to day during the pollen season; as more doctors and patients understand the conditions which affect the pollen count, patients can live more rationally during the pollen season, i.e., staying indoors on evenings of days of bright sunshine, etc.

The pollen count is always, of course, a few days late. But then, when patients go to see the doctor, they are also a few days late. It is thus possible to correlate their symptoms with the pollen count.

Among the summer asthmas, there are some cases of pure fungal-spore sensitivity, such as Cladosporium; others may be complicated by sensitivities. Furthermore, Sporobolomyces may 
be the main cause. The author's patients are requested to keep diaries of their symptoms (some are not anxious to do this) and then later, usually in the winter, their symptoms are correlated with the pollen counts to see if they check. It is also of value to have daily pollen counts and compare them with the counts of the previous year. At the author's clinic, the previous week's pollen and fungal-spores counts, and the corresponding figures for a year previously, are held.

\section{REFERENCFS}

HYde, H. A., 1952. Studies in atmospheric pollen, 5. A daily census of pollens at Cardiff for the six years 1943-48. New Phytologist, 51: 281-293.

Hyde, H. A., 1955. A census of atmospheric pollen and its possible applications. Proc. Linnean Soc. London, 165: 107-112.

Hyde, H. A., 1956. Tree pollen in Great Britain. Acta Allergol., 10: 224-225.

Hyde, H. A. and Williams, D. A., 1953. The incidence of Cladosporium herbarum in the outdoor air at Cardiff, 1949-50. Trans. Brit. Mycol. Soc., 36: 260-266.

Clinical value of daily pollen census--G. L. WaLdborT, Detroit, Mich. (U.S.A.).

For the past 9 years, counts have been carried out by the Bacteriology Department of the Herman Kiefer Hospital, which is a city-owned and managed hospital under the auspices of the Board of Health.

Bacteriologists do the counting. They record the total count as well as the ragweed count. They start about July 19 and terminate the counting with the first frost. The Bacteriology Department passes the information to the Board of Health, and from there it is distributed to newspapers, radio, and television.

Some patients watch the daily count conscientiously, day by day. Others pay little attention to it, realizing that by the time it is available to them ( $24 \mathrm{~h}$ late) the pollen situation in the air has changed.

Patients are taught to anticipate changes in the pollen count by watching weather predictions, particularly barometric pressure, wind velocity, wind direction, total moisture, etc. 